\title{
Model Studies of Lantibiotic Biogenesis
}

\author{
Peter L. Toogood \\ Willard H. Dow Laboratones, Deparment of Chemistry, University of Michigan, Ann Arbor, MI 48109-1055.
}

\begin{abstract}
A six residue polypeptide has been synthesized to study the proposed biosynthesis of lanthionine. It is shown that this peptide spontaneously cyclizes in a biomimetic fashion via a completely stereoselective intramolecular Michael addition to form $(2 S, 6 R)$-lanthionine, as found in naturally occurring lantibiotics.
\end{abstract}

The lantibiotics are naturally occuring antibiotics containing the unusual amino acid lanthionine or methyl lanthionine. 1 This class of modified polypeptides includes nisin, which is used as a food preservative, and epidermin (1, Figure 1$), 2$ which is used in a topical treatment for acne.

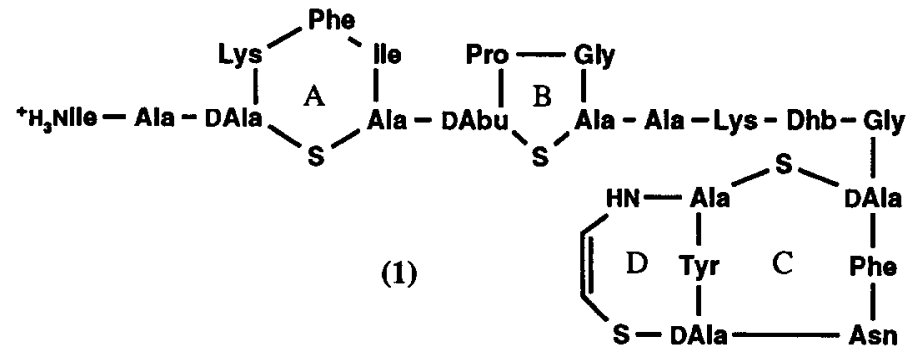

Figure 1. The lantibiotic epidermin (1). Dhb $=(Z)-2,3-$ didehydrobutyrine; DAbu-S-Ala $=(2 S, 3 S, 6 R)-3-$ methyllanthionine; DAla-S-Ala $=(2 S, 6 R)$-meso-lanthionine;

The biogenesis of lantibiotics is intriguing; although extensively post-translationally modified, the lantibiotics have a ribosomal origin. ${ }^{3}$ Inhibitors of protein synthesis suppress the formation of lantibiotics in bacterial cells, and genes for the polypeptide precursors (prepeptides) of several lantibiotics have been identified by DNA sequencing. 2,4 A scheme for the biosynthesis of epidermin has been proposed by Schnell and coworkers, in which the lanthionine residues arise as a consequence of the Michael addition of a cysteine thiol to a didehydropeptide formed by dehydration of a serine or threonine residue. 2,5 Other steps include a proteolytic cleavage to release epidermin from its 52-residue prepeptide, and an oxidative decarboxylation of the terminal lanthionine. The requirement for enzyme catalysis of these various steps has not been determined, and the sequence in which the individual steps occur is not known. We reasoned that while the dehydration of hydroxyamino acid residues is almost certainly enzyme mediated, the subsequent cyclization 
chemistry may occur spontaneously. Furthermore, we anticipated that the stereoselectivity of this cyclization would be dictated by the conformation of the polypeptide chain. 1,6 One prediction of this hypothesis is that longer polypeptides containing the necessary functional groups for intramolecular Michael addition will exhibit higher stereoselectivity than short polypeptides that lack significant secondary structure. 7

To test this hypothesis we decided to synthesize didehydropeptides of increasing length corresponding in sequence to fragments of known lantibiotics such as epidermin. Peptide 4 (Scheme 1) represents a precursor to the epidermin B-ring, except that the (Z)-2,3-didehydrobutyrine residue has been replaced by 2,3-didehydroalanine to simplify the stereochemical analysis. Compound 4 was prepared from fragments 2 and $\mathbf{3}$ as shown in Scheme 1.

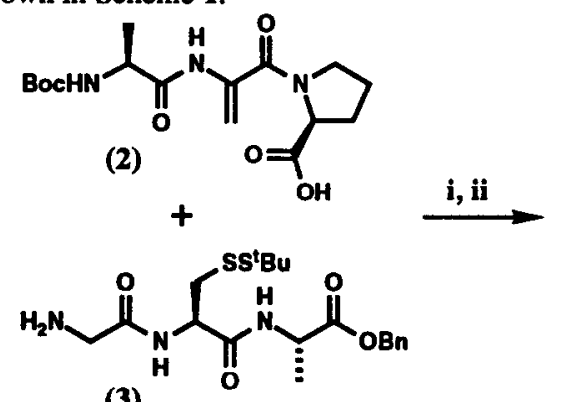<smiles>C=C(NC(=O)[C@@H](C)N)C(=O)N[C@@H](C)C(=O)N[C@@H](C)C(=O)N[C@@H](C)CC(=O)NCC(=O)N1CCC[C@H]1C(=O)OCc1ccccc1</smiles>

(3)<smiles>CCCCC</smiles>

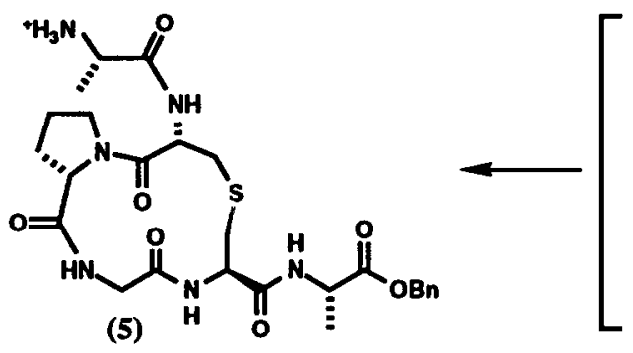<smiles>C=C(NC(=O)[C@H](C)N)C(=O)N1CCC[C@H]1C(=O)NCC(=O)N[C@@H](CS)C(=O)N[C@@H](C)C(=O)OCCCCC</smiles>

Scheme 1. Synthesis of cyclic peptide 5. i. Bop-Cl, NMM, DCM 67\%.

ii. TFA:Phenol: $\mathrm{H}_{2} \mathrm{O}$ :Triisopropylsilane (88:5:5:2) 93\%. iii. $\mathrm{Bu} 3 \mathrm{P}, \mathrm{TFE}, \mathrm{H}_{2} \mathrm{O}$ (1:1) $77 \%$.

Fragment 3 was synthesized in four steps and $53 \%$ overall yield using Fmoc-protected amino acids in solution. The benzyl ester was chosen as a chromophore to aid HPLC purification of the final product. To prepare fragment 2, $\mathrm{N}$-Boc-alanylserine ethyl ester was dehydrated using 1-(3-dimethylaminopropyl)-3-ethylcarbodiimide and copper(I) chloride 8 to give $N$-Boc-alanyldidehydroalanine ethyl ester (73\%). Saponification of the ethyl ester $(78 \%)$ was followed by condensation with proline methyl ester using Bop-Cl to provide the protected tripeptide $(60 \%)$, and hydrolysis of this methyl ester in aqueous sodium methoxide (94\%) gave carboxylic acid 2 as a stable white solid. 
The circular dichroism spectrum of the linear hexapeptide (4) in water at $25^{\circ} \mathrm{C}$ shows a minimum at $-200 \mathrm{~nm}$ indicating that the compound exists predominantly in a random coil conformation as expected. To prepare the cyclic thioether, compound $4(37 \mathrm{mg})$ was dissolved in degassed 1:1 trifluoroethanol:water under nitrogen, at a concentration of $9 \mathrm{mM}$, and tributylphosphine was added dropwise. This mixture was stirred under nitrogen at room temperature for one day by which time cyclization was complete as indicated by the absence of vinylic protons in the ${ }^{1} \mathrm{H}$-NMR spectrum. Evaporation of the solvents, followed by reverse-phase HPLC (C-18; 5:95:0.1 $\mathrm{CH}_{3} \mathrm{CN}: \mathrm{H}_{2} \mathrm{O}:$ TFA) gave pure cyclic peptide 5 in $77 \%$ yield following two rounds of purification. ${ }^{2}$ No evidence could be found for the alternate diastereomeric product. The $360 \mathrm{MHz}{ }^{1} \mathrm{H}-\mathrm{NMR}$ spectrum of compound 5 in $\mathrm{D}_{2} \mathrm{O}$ at room temperature shows two sets of resonances. These resonances coalesce at higher temperatures and only one set of resonances was observed at $338 \mathrm{~K}$ indicating that the cyclic peptide exists as two slowly interconverting conformers at room temperature with one conformer predominating $\sim 3: 1.10$ The configuration at the newly formed chiral center in compound 5 (lanthionine- $C_{2}$ ) was determined by a $500 \mathrm{MHz}$ ROESY experiment ${ }^{11}$ to be $S$ as drawn (Figure 2). This is the same configuration as found at the corresponding position in epidermin (1, Figure 1).
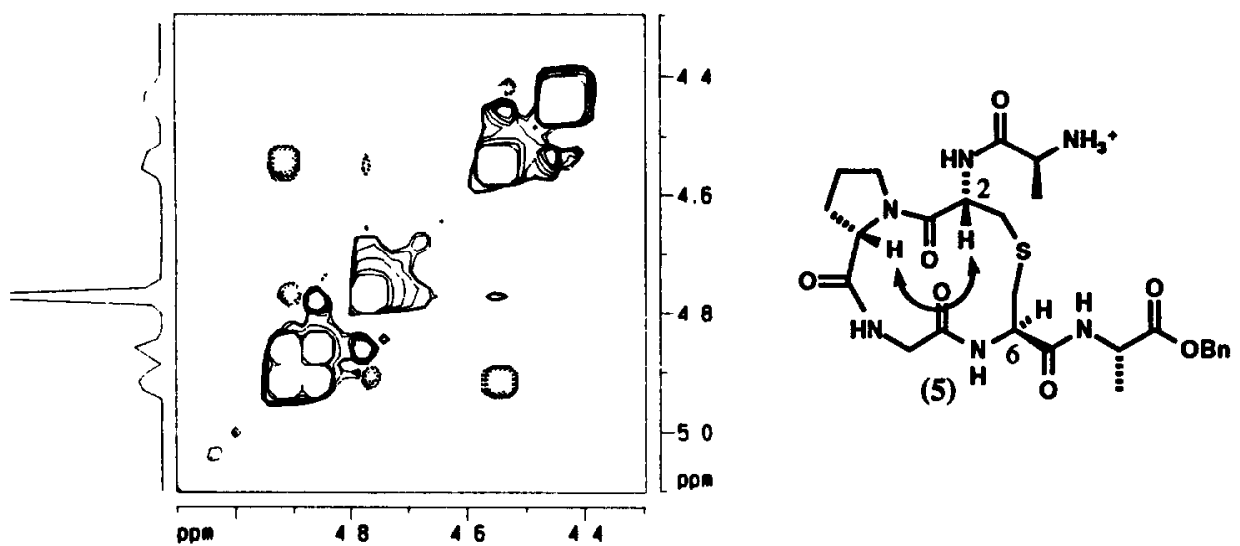

Figure 2. ROESY plot illustrating the nOe between the proline $\alpha$-proton and a lanthionune $\alpha$-proton.

Thus, contrary to our expectations the cyclization of a short peptide such as compound $\mathbf{4}$ can occur stereselectively to give a single diastereomer. Experiments are in progress to determine whether this stereoselectivity arises as a consequence of face-selective addition of the thiol to the Michael acceptor, or whether it occurs as a result of stereoselective protonation of the intermediate cyclic enolate. The conversion of $\mathbf{4}$ to 5 proves that lanthionine residues can be formed in solution via the proposed intramolecular Michael addition route, and that a single diastereomer may be obtained without the requirement for enzyme catalysis. We suggest that this result supports an argument for the spontaneous cyclization of lantibiotic prepeptides in vivo, posssibly during passage across the cell membrane.

\section{Acknowledgements}

We thank Dr. Chris Kojiro for his assistance with the 2D-NMR experiments and Dr. Ruch Lawton for belpful discussions Funding was provided by the Unversity of Michıan. 


\section{References and Notes}

1. Jung. G. Angew. Chem. Int. Ed. Eng 1991, 30, 1051-1068. Jung, G; Sahl, H-G. Eds. Nisin Novel Lantubiotics, Proc. Int. Workshop Lantibiotics, 1st; ESCOM, Le1den., 1991.

2. Schnell, N.; Entian, K-D.; Schneider, U ; Gơtz, F.; Zăhner, H ; Kellner, R ; Jung, G. Nature 1988, 333, $276-278$.

3. Hurst, A. Adv. Appl. Microbiol 1981, 27, 85-123 Ingram, L Biochim. Biophys. Acta 1970, 224, 263-265 U. Schneider, Dissertatıon, 1985, Unıversıtăt Tübingen

4. Kellner, R.; Jung, G.; Josten, M.; Kaletta, C.; Entran, K-D ; Sahl, H-G. Angew. Chem. Int. Ed. Eng. 1989, 101, 616-619. Kellner, R.; Jung, G.; Hörner, T.; Zähner, H.; Schnell, N ; Entian, K-D.; Gołz, F. Eur J Bıchem. 1988, 177, 53-59. Kaletta, C.; Entian, K-D.; Jung, G Eur. J. Biochem. 1991, 199, 411-415. Kaletta, C.; Entian, K-D J. Bacteriol. 1989, 171, 1597-1601. Buchman, G. W ; Banerjee, S.; Hansen, J. N. J. Biol. Chem. 1988, 163, 16260-16266 Banerjee, S.; Hansen, J N. J Biol. Chem. 1988, 263, 9508-9514. Kaletta, C.; Entian, K-D.; Kcllncr, R. Arch. Microbiol. 1989, 152, 16-19.

5 For an example of the diastereoselective Michael addition of a thiol to a didehydropeptide see Schmidt, U.; Ohler, E. Angew. Chem. Int. Ed. Eng. 1976, 15, 42.

6. For conformational studies of lantibiotics see Kessler, H.; Steuernagel, S.; Will, M.; Jung, G.; Kellner, R.; Gillessen, D.; Kamiyama, T. Helv Chim. Acta 1988, 71, 1924-1929. Freund, S.; Gutbrod, O ; Folkers, G.; Gibbons, W. A.; Jung, G. Bıopolymers, 1991, 31, 801-811. van den Hooven, H. W.; Fogolari, F.; Rollema, H. S.; Konings, R. N. H.; Hibers, C. W.; van de Ven, F. J. M. Febs. Lett. 1993, 319, 189-194.

7 The intramolecular Michael cyclization of a short peptide bound to a solid-phase peptide synthesis resin was reported recently by Polinsky et al. $J$ Med. Chem. 1992, 35, 4185-4195 This cyclization unexpectedly resulted in the formation of a single diastereomer However, both we and the authors originally rationalized this result to be the consequence of the cyclization ocurring in the chiral environment created by the neighboring polypeptide chains attached to the resin.

8. Miller M. J. J. Org. Chem., 1980, 45, 3131-2132

9. Data for compound $5[\alpha]^{25} \mathrm{D}+27.3^{\circ}(c 0.007, \mathrm{MeOH}) ;{ }^{1} \mathrm{H}$ NMR $\left(\mathrm{D}_{2} \mathrm{O}, 360 \mathrm{MHz}\right)$ major conformer $\delta 141(3 \mathrm{H}$, d, $\left.J=7 \mathrm{~Hz}, \mathrm{Ala}-\mathrm{CH}_{3}\right), 1.50\left(3 \mathrm{H}, \mathrm{d}, J=7 \mathrm{~Hz}, \mathrm{Ala}-\mathrm{CH}_{3}\right), 1.57-200\left(2 \mathrm{H}, \mathrm{m}\right.$, Pro $\left.\gamma-\mathrm{CH}_{2}\right), 2.08-219(1 \mathrm{H}, \mathrm{m}$, Pro $\beta-\mathrm{CH}), 2.32-$ $2.50(1 \mathrm{H}, \mathrm{m}$, Pro $\beta-\mathrm{CH}), 2.71\left(2 \mathrm{H}\right.$, br t, $J=16 \mathrm{~Hz}$, Lan $\left.\mathrm{CH}_{2}\right), 3.01\left(1 \mathrm{H}, \mathrm{dd}, J=14,11 \mathrm{~Hz}, \mathrm{Lan} \mathrm{CH}_{2}\right), 323(1 \mathrm{H}, \mathrm{dd}, J=16$, $5 \mathrm{~Hz}$, Lan $\left.\mathrm{CH}_{2}\right), 3.46-3.64\left(2 \mathrm{H}, \mathrm{m}\right.$, Pro $\left.\delta-\mathrm{CH}_{2}\right), 3.95\left(2 \mathrm{H}, \mathrm{s}, \mathrm{Gly} \mathrm{CH}_{2}\right), 4.04(1 \mathrm{H}, \mathrm{q}, J=7 \mathrm{~Hz}, \mathrm{Ala}-\alpha), 4.43(1 \mathrm{H}, \mathrm{dd}, J=11$, $4 \mathrm{~Hz}$, Ala- $\alpha$ ), 4.54 (1H, dd, $J=11,4 \mathrm{~Hz}$, Lan 2-CH), $4.86(1 \mathrm{H}, \mathrm{t}, J=4 \mathrm{~Hz}$, Lan 6-CH), $4.91(1 \mathrm{H}, \mathrm{dd}, J=9,3 \mathrm{~Hz}$, Pro $\alpha-\mathrm{CH}), 5.179\left(1 \mathrm{H}, J_{\mathrm{AB}}=12 \mathrm{~Hz}, \mathrm{ArCH}_{2}\right), 5.181\left(1 \mathrm{H}, J_{\mathrm{AB}}=12 \mathrm{~Hz}, \operatorname{ArCH} H_{2}\right), 7.45(5 \mathrm{H}$, br s, $\operatorname{Ar} H) ;{ }^{13} \mathrm{C} \mathrm{NMR}_{2}\left(\mathrm{D}_{2} \mathrm{O}\right.$, $50 \mathrm{MHz}) \delta 18.34,19.31,3417,3783,38.49,46.59,50.45,51.41,5153,54.99,55.16,62.92,70.10,130.70,131.19,131.33$, $172.77,173.29,174.35,174.35,176.38,177.37$; MS $m / z$ FAB (3-NBA/TFA) $599\left(5, \mathrm{M}^{-N^{+}}\right), 577\left(100, \mathrm{M}^{+}\right), 398(6), 329$ (7), 273 (24), $176(13), 91$ (48); (found $\left(\mathrm{M}+\mathrm{H}^{+}\right)$, 577.2430. $\mathrm{C}_{25} \mathrm{H}_{36} \mathrm{~N}_{6} \mathrm{O}_{7} \mathrm{~S}_{2}$ requires 577.2444).

10 A similar compound prepared by Palmer and coworkers exists as a single conformer in DMSO-d 6 . Palmer, D. E.; Mierke, D. F.; Pattaroni, C.; Goodman, M.; Wakamiya, T.; Fukase, K.; Kitazawa; M., Fujita; H., Shıba, T. Bıopolymers, 1989, 28 , $397-408$.

11. Bothner-By, A. A.; Stephens, R L.; Lee, J.; Warren, C. D ; Jeanloz, R. W. J Am Chem. Soc. 1984, 106, 811-813. Bax, A.; Davis, D. G. J. Mag Res 1985, 63, 207-213. ROESY was performed at $500 \mathrm{MHz}$ with a mixing time of $300 \mathrm{~ms}$ and a spinlocking field of $3 \mathrm{KHz}$ employing 2D phasing according to States et al 12

12. States, D. J.; Haberkorn, R. A ; Ruben, D J J. Mag Res. 1982, 48, 286-292

(Received in USA 11 August 1993; accepted 29 September 1993) 